\title{
Editorial \\ What is Populism? \\ Who is the Populist?
}

\author{
Jean-Paul Gagnon, Emily Beausoleil, Kyong-Min Son, \\ Cleve Arguelles, Pierrick Chalaye, Callum N Johnston
}

Both "populism" and "populist" have long been considered ill-defined terms, and therefore are regularly misapplied in both scholarly and popular discourses. ${ }^{1}$ This definitional difficulty is exacerbated by the Babelian confusion of voices on populism, where the term's meaning differs within and between global regions (e.g. Latin America versus Western Europe); time periods (e.g. 1930s versus the present), and classifications (e.g. left/ right, authoritarian/libertarian, pluralist/antipluralist, as well as strains that muddy these distinctions such as homonationalism, xenophobic feminism and multicultural neonationalism). While useful efforts have been made to navigate the vast and heterogeneous conceptual terrain of populism, ${ }^{2}$ they rarely engage with each other. The result is a dizzying proliferation of different definitions unaccompanied by an understanding as to how they might speak to each other. And this conceptual fragmentation reinforces, and is reinforced by, diverging assessments of populism which tend to cast it as either "good" or "bad" for democracy (e.g. Dzur and Hendriks 2018; Müller 2015).

To open this edition of Democratic Theory - one that takes the vagarities, complexities, and implications of contemporary populism as its focus - we wish to contribute to this effort to clarify core concepts by offering an account of the six lines that have been drawn to distinguish between different forms of populism within the literature on populism and populists from 2008-2018 (what we heretofore refer to as "the corpus"). While introducing these cleavages may not fully overcome the conceptual challenges posed by populism, it has the benefit of allowing us to approach populism less as a fixed entity that can be captured by a single definition and more as a shape-shifting phenomenon which moves along multiple, crosscutting cleavages. We suggest that the six cleavages introduced here can serve as a heuristic through which we can come to terms with diverse manifestations of populism. We also believe that 
this heuristic can help develop clearer interpretive grounds for making more normative claims regarding forms of populism that prove "good" or "bad" for democracy-among the most muddy and troubled waters in this current political moment.

In the contemporary literature (2008-2018), populism is often divided into left and right variants. Populism, particularly in postmillennial politics, typically refers to right populism, which is characterized by emotionally-charged political appeals to addressing crises through neonationalism, masculinism, Othering, bordering, xenophobia, sexism, racism, phantasmatic ethnic golden-ageism, a disregard for liberal democratic norms, and so forth. Highlighting these features, a number of observers describe (right) populism as a parasite of liberal democracy which grows in times of crisis to ultimately endanger its host (Müller 2016; Urbinati 2014). Other thinkers dispute this description of populism, however. Mouffe (2016) asserts that while populism "is usually used in a negative [pejorative] way" through such descriptors, to account for all populism in such terms "is a mistake." Mouffe and others make the distinction of a second form of populism that might be reclaimed by progressives so that it can contest right populism in formal arena politics today. Left populism, or progressive populism (Fraser 2017), is said to hold the potential to address crises in a manner which secures the democratic project (Canovan 1999; Dzur and Hendriks 2018; Tamás 2017; Tormey 2018) by deepening the legitimacy of real-existing democracies and upholding civic, political, and economic rights alongside material egalitarianism - typically through a stance open to immigration and refugees and one that is adversarial to the power and privilege of financial capital, the drivers of pollution, and natural systems destruction.

Populisms as they exist, however, do not neatly match this left-right divide. Populism is ideologically ambiguous or "thin-centred," that is, it attaches itself to diverse (and sometimes even contradictory) ideological projects depending on the political moment (Mudde and Kaltwasser 2018). This means, as Canovan (1982) observes, that different constituencies can respond to disparate aspects of a populist movement, creating an alliance defying conventional ideological lines (e.g., a xenophobic but economically progressive populist party). Equally important, the left-right dichotomy tends to generate a one-dimensional assessment of populism: it is either "good" or "bad" for democracy. (It is not a coincidence that right populism is largely a creation of populism's liberal critics, and left populism a creation of its radical or progressive advocates.) It is our suggestion that tracking populism's movement along the cleavages we identify can help us think beyond this binary, and permit a more nuanced evaluation of populism's perils and democratic possibilities (e.g. Babones 2018). 
Because populism typically positions itself against democracy, for better or worse, one's assessment of populism is closely related to a perception of the current state of democracy. We agree with the literature suggesting that it is the crises of minimalist, electoral, representative, and capitalist democracies (heretofore "real-existing democracies") that we have to thank for the rise of populism (e.g. Beyme 2011; Corduwener 2014; Fraser 2017; Norris and Ingleheart 2018: 6; Pasquino 2008), though we also recognize that it can also be the success of such regimes in facilitating cultural change (e.g. globalization) that fuels populism's more "nostalgic" authoritarian variants (Diamond et al. 2016; Norris 2016). The right, the left, and, as Tim Bale (2013) suggests, even the centre, could adopt the style of populism to reap electoral rewards, because of common perceptions that real-existing democracies are either dysfunctional, corrupt, or hollowed-out (Bailey et. al. 2018; Crotty 2014; Fishman 2016; Fuentes 2013; Mainwaring and Pérez-Liñán 2013; Mitchell 2009: 41; Morlino et al. 2013; Qizilbash 2008). This has built a significant demographic of people - liberal and illiberal - who feel betrayed by the very institutions that profess to serve them. But while deficiencies of real-existing democracies are widely recognized, there is uncertainty and disagreement about how to respond to the populist surge. Should we try to contain its extremism (Rummens and Abts 2010) or embrace it as long as it does not engage in explicit violence (Müller 2016)? Or, instead of trying to preserve liberal democracy, should we try to rectify its fundamental limitations by promoting a "progressive populism" (Frazer 2017; Mouffe 2018)?

While "left" and "right" are perhaps the most common ways of classifying populism, those designations are actually a composite of multiple cleavages. In the sharply divided debate, a particular mobilization of cleavages is often reified as a permanent definition of populism, and we are left with intellectual confusion whenever populism's variety and mercuriality inevitably elude that definition. For a more precise analysis of patterns and tensions within and between populist movements, we propose to disaggregate the broad definition of populism into the following six cleavages: (1) authoritarian and democratic, (2) market fundamentalist (libertarian) and redistributive, (3) exclusionary and inclusionary (antipluralist and pluralist), (4) xenophobic and cosmopolitan, (5) electoral and participatory (thick) (6) nostalgic and aspirational. Below we will first outline these cleavages and then illustrate how they might shed light on seemingly infinite and bewilderingly various phenomena that are characterized as "populist" and "populism" in the corpus. We will close with some thoughts on populism's challenges to democracy and how we might address them. 


\section{What is Populism?}

As the name suggests, if populism has a single defining characteristic, it may be the invocation of "the people" who are betrayed, wronged, or otherwise left vulnerable to forces outside their control. In fact, we find in the corpus that populism is typically a reaction to a deep crisis, real or perceived, in diverse and large democracies. ${ }^{3}$ Of course, the culprit of the crisis as well as the identity of the victimized people are highly contested and vary widely. Mark Elchardus and Bram Spruyt (2016), for instance, surveyed 2,230 Dutch-speaking Belgians and determined that it was the declinism perceived by this group of Flemish people in Belgium - the social discontent of their feeling unfairly treated by society and their inability to address this through formal politics (Spruyt, Keppens, and Droogenbroeck 2016) - which fueled their support for the Vlaams Blok (VB), a radical right populist party in Flanders (Mudde 2012). Another survey, this time from the USA during Trump's campaign for the presidency, shows that his style and rhetoric appealed to Americans weary of expertise, elites, and critical nationalism (Oliver and Rahn 2016) because Trump could connect with people that became "cultural outsiders" (Smith and Hanley 2018) in an increasingly progressive American society that "left them behind" (see Berezin 2017, who suggests certain retired servicepersons of Viet Nam and their disadvantaged children, persons without higher education, and those working in manufacturing and the military, are among Trump supporters). A sense of crisis, then, challenges the effectiveness of existing modes of democratic representation of "social interests, values and demands", making conditions that are more conducive for populist emergence (Roberts 2015).

The wide variety in the driving force as well as major agents and supporters of populism makes it exceedingly difficult to attach general properties or "logics" to populism, apart from the fact that it speaks in the name of the people. Is populism necessarily antipluralist? Is it fated to degenerate into authoritarianism? Is it axiomatically incompatible with representation of any kind? Our review of the corpus suggests that one is hard pressed to answer these questions definitively. Rather, populism seems to move along different cleavages, finding a contingent, though not random, position depending on the nature of the crisis it responds to, the political and socioeconomic structure populists find themselves in, and, of course, the populists' actual political practice.

As just noted, populism is often animated by a crisis. The crises that have contributed to what Benjamin Moffitt (2016) terms "the global rise of populism" over the 2008-2018 period have been in the main about the economy (i.e. financial crises, job losses, wage stagnation, affordable 
housing), sovereignty (i.e. missing corporate taxes, "mass illegal" immigration), and security (i.e. terrorism, climate change, dwindling social nets, democratic decay). Each of these policy areas make good examples to demonstrate populism's reactive but also productive character as populist actors subjectively construct and perform crisis as much as they react to it (Moffitt 2015). And, considering competing conceptions of populism in light of these examples illustrates why it is limited, if not misleading, to explain populism by a single definition. Because populism reacts to conditions that vary across different contexts, its working can be better understood when we investigate how it groups and regroups different cleavages. Here, we will work through the example of the economy for reasons of concision. For populism's relation to sovereignty see Daphne Halikiopoulou, Kyriaki Nanou and Sofia Vasilopoulou (2012, EU-focused) and for its relation to security see Christina Liang (2016, also EU-focused) for a start.

Dani Rodrik (2018: 23) writes about how the success of globalization - the rise of multi and transnational corporations, their investors, banks, insurers, and the managerial and professional classes that power them - came to drive a wedge between "capital and labor, skilled and unskilled workers, employers and employees, globally mobile professionals and local producers, industries/regions with comparative advantage and those without, cities and the countryside, cosmopolitans versus communitarians, elites and ordinary people." The "cruel lottery of the market" has economically benefitted some, writes Rodrik - like China's formerly agrarian poor-while leaving others in economic decline or destitution, such as people in postindustrial parts of for instance the US, Canada, Australia and the UK. "A dynamic of global economic development means that many countries are experiencing uneven development and their citizens are increasingly split between those who can access high-skill jobs and those who cannot," write Will Jennings and Gerry Stoker (2016: 372), and "[a]s a result some citizens are living in cosmopolitan areas of growth and others in backwater areas of decline." As such, whether for or against it, a generation of populists emerged and found relevance in representing diverse concerns about the increasing social, economic, and political costs of globalization (Aytac and Öni 2014).

The populist responses to economic crises, such as the Global Financial Crisis (GFC), are widely known and still much discussed in both academic and non-academic forums. The six cleavages we encountered in the corpus help classify these responses to the GFC and we use them as a heuristic to make some sense of populism. It should be noted that the literature associated with each cleavage is complex as several descriptions of populism are arguably synonymous, so there is a degree of conceptual 
overlap between cleavages. There is, too, the difficulty of trying to make sense of literature which claims to be discussing, say, progressive populism in toto but that is actually working from an evidence base rooted in, for instance, the European Union (EU) and therefore its findings will likely confuse readers from different parts of the world. We recognize that there is little chance of disentangling this knot of knots and therefore proceed with our heuristic which is attuned to these provisos.

(1) Authoritarian populism supports "transgressive strongman leaders" who are "willing to express politically incorrect views" so long as this defends "traditional values and beliefs" such as keeping jobs at home and people in fairly paid work (Norris and Ingleheart 2018: 17). Authoritarian populism tends to perceive legal rules and constitutional norms as obstacles to the swift exercise of authority, and resort to illiberal tactics that can lead to democratic deconsolidation if this approach is entertained for too long by the political mainstream (Mietzner 2018). McCoy (2017) even adds that "strongmen populists" may also occasionally resort to the use of "performative violence" to demonstrate political will and domestic strength. Democratic populism looks to grassroots, bottom-up, mobilization of peoples to counteract the pathologies of the global neoliberal economy (see Morlino and Raniolo 2017: 69 for the southern European case).

(2) Market fundamentalist (libertarian) populism places blame on what they perceive to be inefficient government, unaccountable experts, and dependent welfare recipients, promoting the capitalist market where unrestrained competition supposedly gives all individuals an equal and fair opportunity for success (Frank 2001). In contrast, redistributive populism looks to rein in global economic elites and redistribute wealth. Redistributive populism can manifest in various ways, from progressive attempts to regulate the market economy (Quaglia 2012) and to achieve a just economic system in which "[e]verybody does better when everybody does better" (Frazer 2017: 70) to protectionist measures against globalization (Munck 2009, specifically in the Latin American context) and even to ethnonationalist fantasies of returning to an economic golden age where one earner was enough to sustain the household (Baum 2017).

(3) Exclusionary (antipluralist) populism asserts that it represents the singular will of the authentic people, denying legitimate economic competition and implying that "whoever does not support populist parties might not be a proper part of the people" (Müller 2016: 3), whereas inclusionary (pluralist) populism recognizes "the vital necessity of divisions within the people" as a crucial link to the never-ending task of emancipation (Stavrakakis 2014: 514) and tries to involve all groups, especially those who feel threatened, "through radical political solutions [to economic problems] in a democratic way" (Markou 2017: 55). 
(4) Xenophobic populism "privileges the organic understanding of the 'people' as an ethnically or culturally homogeneous totality," a totality that is threatened by "the dissolution of their identity," and who confront such perceived threats "by excluding weaker groups" by for instance resisting economic migrants (Filc 2011: 223) whereas cosmopolitan populism tries to assert the transnational modernization project without disparaging localities: it can be a mode of political "glocalism" in the pursuit of "social security, equality, and democratic accountability" (Brasset 2010) within, between and beyond states and their economies (Dryzek 2008).

(5) Electoral populism focuses on taking control of governmental institutions, ultimately through electoral politics as means to reformulate economic policies. Participatory, or "thick," populism is oriented toward ordinary citizens' self-organizing practices, everyday spaces of public action, and the institutional reform of the economy with the government as a potential partner in this process (Dzur 2010: 370). It often involves efforts to protect and reinvigorate local communities, typically rural ones, through "collective action on the part of relatively powerless organized community interests" for equitable economic development (McDonagh et al. 2009: 19).

(6) Nostalgic populism "embodies the legacy of romanticism: the implicit, clairvoyant sense of the traditional and thus the natural wisdom of the masses" which, William Epstein (2017: 46) argues, perpetuates material inequalities whereas aspirational populism mobilizes "the aspirations of ordinary people to exercise power over their everyday lives and their collective fate" (Grattan 2016: 10) to reverse their dwindling economic conditions.

Although our demonstration of these six cleavages is a simplification of populism's discursive and semiotic complexities, ${ }^{4}$ identifying populism's "field of movement," as it were, is useful to understand concrete political phenomena beyond the monolithic label of "populist" and as what they actually are - a complex positioning in a field created by disparate yet intertwined cleavages. In the next section, we will try to illustrate this point by analyzing some of the recent political events through the lens of these cleavages.

\section{Who is the Populist?}

A populist can be an individual, a political party, or a social movement Albertazzi and McDonnell (2015: 3-7; Lazaridis et al. 2016; Weyland 2001, 2003, 2013). Such agents are given the populist moniker because they 
adopt a certain style of behavior, discursive frame, or thin ideology (e.g. Aslanidis 2016; Moffit 2016; Mudde and Rovira Kaltwasser 2013) in which everyday citizens are framed as in need of regaining control over the political institutions that were meant to serve them, institutions which are felt to be corrupted by elites to serve the interests of the opulent minority, the Other, the few hegemons near and far. ${ }^{5}$

Examples of populist individuals have, it feels, never been more abundant. Hugo Chavez (PSUV), Alberto Fujimori (e.g. Cambio 90), Ted Cruz (GOP), Carlos Menem (JP), Evo Morales (MAS), Marine Le Pen (FN), Geert Wilders (PVV), Rodrigo Duterte (PDP-Laban), Silvio Berlusconi (FI), Victor Orbàn (Fidesz), Recep Tayyip Erdogan (JDP), Jeremy Corbyn (Labour), Beppe Grillo (5 Star), Jörg Haider (BZO), Nigel Farage (UKIP), Donald Trump (GOP), Sarah Palin (Tea Party), and Pauline Hanson (One Nation) all either identify as, or have otherwise been labelled, populist. ${ }^{6}$

This promiscuous list of populists reflects the conceptual proliferation in the contemporary populism debate which verges on fragmentation. The cleavages we derived from the corpus can bring into focus a number of crucial distinctions obscured by the totalizing label of populism. For example, Bernie Sanders and Donald Trump are commonly called populists. This is not exactly incorrect, but only in the broadest and not very helpful - sense that they both claim to be representing people who have suffered in America's "rigged" system. We may be able to characterize them as left populist and right populist, except that those terms, too, are used quite loosely to include everything "good" and everything "bad" from the democratic standpoint. This is why, we suggest, it is helpful to disaggregate populism into its different cleavages. Even in the realm of economic policies, we can gain a more precise understanding of Sanders and Trump when we deploy the market fundamentalist-redistributive cleavage. Trump's economic protectionism and anti-globalism, the debate about its sincerity aside, can be considered at least to contain redistributive thrusts. On the other hand, his crusade against economic regulation and tax policies betray a strong market fundamentalist orientation. Seen in this light, Trump is not simply right populist; he oscillates between the market fundamentalist and redistributive poles, and sometimes simultaneously, if unevenly, assumes multiple positions in the spectrum. Similarly, the authoritarian-democratic cleavage is helpful in differentiating the two figures. Seen through the lens of this cleavagewhere authoritarian "leaders adopt policy positions which endorse the values of tough security against threats from outsiders, xenophobic nationalism rather than cosmopolitanism, strict adherence to conventional moral norms, and intolerance of multiculturalism" and democrats, in short, do the opposite (Norris and Ingleheart 2018) - Trump clearly veers 
to the pole of authoritarian populism and Sanders that of democratic populism. Here we can recognize that, notwithstanding all these stark contrasts, both Sanders and Trump largely remain electoral populists.

Parties and movements, like politicians, can also be analyzed more precisely through the lens of crosscutting cleavages. Take the case of homonationalism for example. Ann-Cathrine Jungar and Emil Edenborg (2018) at the International Political Science Association's world congress in Brisbane, 2018, demonstrated that the "Danish People's Party, Norway's Progress Party, the Sweden Democrats and the True Finns are positioning themselves on issues of gay inclusion and trans rights" because of their countries' cultural reliance on being progressive - at least in terms of valorizing LGBTQIA+ acceptance and inclusion. Homonational parties try to legitimize themselves through alliances with members of, for example, the trans community who are in favor of hard borders and limiting immigration - specifically from Muslim countries due to their perception of Muslims being intolerant around issues of gender and sexuality. Trans people join with xenophobic nationalists out of fear, and nationalists join with trans people to win votes. Whereas it is expected that these homonationalist parties will turn on their trans allies (Puar 2017) if electoral success is experienced, such assemblages still pose a difficult methodological question for political scientists. If a party is both socially conservative but also progressive, xenophobic but also pluralist, what is it?

A different example from this perspective is the recent success of the coalition formed between the Five Star Movement (FSM) and the Lega Nord (LN) in Italy's 2018 general elections. The FSM promotes same sex marriage, universal citizen's (basic) income, a strong environmental agenda and advocates direct democracy (Bouillaud 2016, Hermet 2017) while being ambiguous on questions of immigration. LN is built on a xenophobic and socially conservative line, originally targeting "corrupted" South Italy and recently adopting a more direct anti-immigrant, anti-Islam, and anti-European rhetoric while denouncing same-sex marriage as a danger for "traditional" family values (Agnew \& Shin 2017, Ivaldi \& Lanzone 2017). Despite these value differences both parties have formed a coalition.

Or, observe the populist politics surrounding austerity measures in the EU. A segment of northern Europeans may wish for the south of Europe to pay their debts even when they are ideologically sympathetic to redistributive schemes proposed by some of the crisis-ridden southern European countries, because they believe southern Europeans are not as hardworking and frugal as they are, but without caring much about preserving the financial integrity of the EU. Likewise, those who protest against austerity programs may do so because they recognize those debts as imposed by the EU's 
"foreign" authority or as a product of skewed market competition, even when they are in large part committed to the EU project and are distrustful of their national governments (Krastev 2012: 5). In the cases of homonationalist parties, the FSM-LN coalition, and the contention over austerity programs, all-inclusive categories such as left and right populism clearly cannot account for multiple and at times conflicting allegiances animating populism. But when we approach populism in terms of multiple cleavages, encountering, say, an inclusive yet xenophobic or a xenophobic yet redistributive populism as such does not have to land us in intellectual paralysis.

There may be affinities between poles of different cleavages. For example, the exclusionary or xenophobic pole, where the issue of the "Other" looms large, may be pulled to the authoritarian pole with more ease and speed. For the xenophobic populist, immigrants, foreigners, those who look different, act different, and speak different, to whatever the populist expects to see as the "way of the nation" are scapegoated as job-stealers, criminals, house gobblers, welfare burdens, nation breakers - corruptive elements who must be ejected from the state and held back at hard borders. Therefore, the xenophobic populist takes "security" to be of paramount importance and supports decisive state action even at the expense of the rule of law, justice, and sometimes common sense (e.g., the Trump administration's travel ban, border control, and crackdown on illegal immigrants). ${ }^{7}$ Also, the xenophobic pole might have a strong affinity with the nostalgic pole (e.g., "make America great again"), as the latter envisions a fantastical past "uncontaminated" by foreign elements.

Cross-regional comparisons are also made more productive when undertaken through the lens of various cleavages. While Trump and Philippine populist Rodrigo Duterte are commonly argued to have a "similar political style" (Curato 2016), they have significant political differences that are accidentally sidelined by this comparison. Trump and Duterte converge on authoritarian, libertarian and electoral poles while at the same time meaningfully diverging on the other cleavages. Trump demonized Muslims and other immigrants as the "American Other" while Duterte repeatedly made public appeals to the majority Christian Filipinos to address the enduring "historical injustices" faced by Muslim Filipinos. The same can be extended to the case of comparisons being made between Thailand's Thaksin Shinawatra and Fujimori (Phongpaichit and Baker 2008). Approaching populism from the perspective of a variety of cleavages allows for fruitful comparisons without sacrificing context.

Disaggregating populism into different cleavages is also helpful in confronting the challenges facing those who see populism as the opportunity to deepen democracy. Despite the common aspiration to protect the people and resist elites, their primary concerns and allegiances are diverse, 
if not fragmented (Gomez et al. 2016) - perhaps because of the electoral successes that radical right parties experienced after the fall of communism and because of how financial capital benefited under third way politics which loosened Marx's posthumous grip (see March 2012 for several explanations). ${ }^{8}$ As Luke March (2011) writes: the radical left parties, those "left of left", have only just "begun to recover from the collapse of communism" and are hoping to represent the kaleidoscope of progressive electors once they are able to reconnect with them in formal politics (March 2012). The corpus documents positions held by those populists who are trying to secure the democratic project. Among them is a dominant rejection of Othering and the power of financial capital (Harrison 2015) with at times an environmental or "green" concern (Bomberg and Schlosberg 2008: 338339). Such populists also tend to be culturally progressive and therefore less prone to nostalgic fantasies. There is, too, a hostility to polluting practices, material inequality, mainstream political institutions, hard borders, and the privatization of national assets and services. These populists tend to prefer thick (Dzur and Hendriks 2018), inclusive (Stavrakakis et al. 2016), and in some groups more radical reform-oriented (March and Rommerskirchen 2015) modes of pluralistic democratic practice. While these are all admirable commitments, the recognition of populism's multiple cleavages also reminds that those commitments will not naturally or easily cohere into a viable political coalition simply for their individual virtue. It will require creative and patient intellectual and political work.

\section{"Populists" and Their "Populisms": What Heralds for Democracy?}

While crises may be a proximate catalyst for populism, it bears emphasis that the general dysfunction of institutions in real-existing democracies are centrally to blame for "the global rise of populism" (Moffit 2016). Numerous works in psychoanalysis (e.g. Oppenheim 2018), social theory (e.g. Moffit and Tormey 2013), and ethnography (e.g. Arguelles 2017) lend support to the thesis that the roots of the recent populist surge are not shallow but deep. The problem is not just the failure to prevent or "properly" deal with the GFC. Rather, it is citizens' perception that real-existing democracies are performing poorly or outright failing in a long list of policy fields, and that this is a chronic problem. Populism, regardless of its particular position in the cleavages outlined above, poses a fundamental challenge to the legitimacy of real-existing democracies: populists are saying that democratic institutions are not fulfilling their functions, so much so that citizens are compelled to seek more direct forms of democratic influence. 
If the nature of populism's challenge is clear, it is far from clear what populism heralds for democracy and how we might respond to it. Our review of the corpus suggests that any blanket judgment that populism is either "good" or "bad" for democracy is difficult to sustain. Where a particular populism is crystallized in the intersecting web of cleavages, not its supposedly universal logics, is more important in understanding its implications for democracy. Pace some liberal critics, therefore, we should avoid a wholesale dismissal of populism and take representative democracy's limitations more seriously. When we put only the stability of liberal democracy in the limelight, we risk obscuring - or worse, reproducing - the very problems that gave rise to populist protests in the first place. At the same time, pace radical admirers of populism, we should be more alert to the tension between populism's multiple cleavages and the possibility that promoting one (say, redistributive) pole does not necessarily entail - and perhaps does not even facilitate - the movement toward other desirable poles (such as the inclusive or participatory ones).

As we grapple with populism's challenges, we need to be sensitive to emotional volatilities engulfing many democracies today. Working through the literature on populism, we found that people are drawn to populism not simply because of the objective hardship caused by the GFC, but because they are angry, disappointed, despondent, shocked, and frustrated. As Martha Nussbaum (2018) carefully notes for the American case, it is understandable that fear becomes a powerful social mood when a large section of a society experiences economic decline. Health problems tend to increase, university degrees become harder to afford, and the future-especially for one's children - might not look as bright anymore. This rocky emotional terrain poses a delicate challenge to an array of projects intended to deepen democracy. It makes, for instance, a long deliberative democratic process to establish an economic democracy (Malleson 2014) feel intolerably slow and unrewarding, while making blaming Others or the conspiring global elites look like an attractive alternative - which is misplaced and reprehensible, to be sure, but promises a quick release of pent-up anger.

This does not mean that we have to give up the incontrovertibly important work of civic education, political mobilization, and public deliberation, or suspend the essential effort to enhance the legitimacy of still operating institutions in real-existing democracies (e.g. Snyder 2017; Sunstein 2018). Despite the anxieties around populism, populist publics are also hopeful (Curato 2017). In populism, they see possibilities of reclaiming their esteem as democratic agents who can exercise control over their lives. This does suggest, however, that we should not dismiss populism's 
yearning for more direct forms of political engagement merely as naïve or reckless. (We would do well to remember that the current form of democracy is in large measure a product of struggles against precisely such accusations.) We do not have to believe in a world fully at one with the will of the monolithic people to think that the current chasm between the entrenched mechanisms of democracy and most citizens is unsustainably deep. And we may be able to narrow that chasm not simply by mending conventional democratic institutions but, perhaps, also by expanding the horizon of democracy beyond them.

This issue, as can be inferred from the preceding long-form editorial, begins with a special section on populism and its relationship with democracy. Democratic Theory's editors put together this section to pursue several questions that came out of a workshop entitled "After Populism: Can Democracy Survive and Renew Itself?" held 7 April 2017, at the Institute for Governance and Policy Analysis, University of Canberra. Benjamin Moffitt (in this issue) analyses the populism versus anti-populism cleavage in Western Europe and arrives at the conclusion that there is an agonistic struggle between on the one hand radical and popular democracy and on the other liberal democracy. Adherents to both populist poles take concern with nationalism and nativism - it is these tendencies, and not the struggle between models of democracy, that constitute Western Europe's “populist threat.” Adele Webb (in this issue) critiques and defends the concept of democratic ambivalence where a citizen can "say yes and no at the same time," "vote and then judge," and think about democracy as an entity that exists outside of elections. "[A]mbivalence can be a form of participation in democracy that is crucial to safeguarding its future," writes Webb (this issue, p. 31), and it is dangerous for people to shut the tendency to ambivalence down. A citizen's ambivalence toward democracy needs recognition, discussion, and resolution lest it unnecessarily boil into the resentment of democracy. And Mary Walsh (in this issue) crafts a defense of progressive populism by arguing that it followed the financial successes of corporations and transnational capitalist elites. Corporations, or "big businesses," have refigured liberal praxis into a paradoxical pantomime of itself in order to gain freedom from democracy - to be unfettered from electors, to selfishly benefit under parliamentary legislation and state regulation, to do what they are legally obliged to do which is make as much profit as quickly as possible. As Walsh demonstrates, progressive populists are deeply antagonistic toward this state of affairs and that their politics are therefore inherently valuable to redistributive, socially-oriented, democratic futures. 
We are pleased to write that this issue offers a second special section. In their article, Matthew Flinders and Matthew Wood seek to "contribute new conceptual and theoretical depth" to existing frameworks of "everyday politics." Flinders and Wood critique instances of existing "everyday politics" via Michel Maffesoli's social theory "to posit a framework for determining whether nontraditional forms of political engagement can be defined as genuinely distinctive from traditional [political] participation." In response to their argument, Max Halupka demonstrates that Flinders and Wood's "take on intentionality lacks consideration of the complexities that the online space attribute," Sadiya Akram with David Marsh state that the authors "misspecify the new forms of this participation, so are unable to provide a more adequate theoretical frame for future research," and Pia Rowe also with David Marsh "highlight the importance of the protopolitical sphere in particular in the digital environment."

The issue rounds off with a practitioner's note by Spencer McKay and Peter MacLeod on Toronto-based MASS LBP - a private firm specializing in designing and running citizen panels for governments and businesses; a review essay by Greta Snyder (featuring David McIvor's Mourning in America and Simon Stow's American Mourning); and a book review by Anna Shön (Kevin Olson's Imagined Sovereignties: The Power of the People and Other Myths of the Modern Age).

\section{Acknowledgments}

The editors would like to thank Kyong-Min Son, Cleve Arguelles, Pierrick Chalaye, and Callum N Johnston for co-authoring the state of the field review (2008-2018) that prefaces this issue. Thanks also go to several panels on populism held at the International Political Science Association's world congress in Brisbane, 2018, and the Alfred Deakin Institute's workshop entitled "Contemporary Democracy and Its Critics" held in Melbourne on 19 July 2018. (Special thanks to Zim Nwokora for organizing the latter.) Papers presented at these gatherings were instrumental to the development of this long-form editorial on the populisms and populists of our contemporary political period.

Kyong-Min Son is Assistant Professor in the Department of Political Science \& International Relations, University of Delaware. E-mail: kmson@udel.edu

D Cleve Arguelles is Assistant Professor and Chair of the Political Science Program, University of the Philippines - Manilla. E-mail: cvarguelles@up.edu.ph 
D Pierrick Chalaye is a $\mathrm{PhD}$ Candidate at the Centre for Deliberative Democracy and Global Governance, University of Canberra. E-mail: pierrick.chalaye@ canberra.edu.au

Callum N.Johnston is an Honours Dissertation Candidate at the School of Governance \& Policy, University of Canberra. E-mail: u3143046@uni.canberra.edu.au

\section{NOTES}

1. See Mudde 2004; Weyland 2001; Stoica 2017; Woods 2017; Pappas 2016; Jansen 2015: 159; Bale, Van Kessel and Taggart 2011; Canovan 1999: 3, 1982; Woods and Wejnert 2014; Gidron and Bonikowski 2013: 1.

2. See Stockemer 2019; de la Torre 2019; Norris and Ingleheart 2018; Müller 2016; Moffitt 2016; Albertazzi and McDonnell 2015; Müller 2015; Moffitt and Tormey 2013; Mudde and Rovira Kaltwasser 2012; Albertazzi and McDonnell 2008.

3. The corpus deals mainly with "full-democracies" which brackets our observations and analysis. There is evidence, however, in the corpus for populism in non-democracies as well. For populism in a "non-democracy" like China see Lynch (2018).

4. We view the six cleavages covered in this editorial as the "dominant" or "mainstream" ones in the corpus. On the fringes are transnational populism versus national populism, institutional populism versus anti-institutional populism, popular populism versus unpopular populism, and liberal populism versus illiberal populism. We also ran into the concepts of technocratic populism (Buštíkovà and Guasti 2018), neoliberal populism (Bozkurt 2013), modernist populism (particularly Latour 2017 in contra-distinction to terrestrialism), penal populism (Dzur 2010), anti-EU populism (Grabbe and Groot 2014), antiBrussels populism (Krastev 2012), Islamist populism (Boduszyński and Pickard 2013), religious populism (Filc 2009), Jewish populism (Filc 2009), white populism (Ali 2010), and black populism (Ali 2010) but these variants were not part of a pronounced polar pair (i.e. there was no obvious cleavage between a substantive body of literature) and therefore were not included in our heuristic.

5. Kurt Weyland (2001:1) writes that governments and policies can also be populist but, as governments are formed by political parties and policies stem from parties, it is, we feel, sufficient to limit populist agency to parties as Daniele Albertazzi and Duncan McDonnell (2015) have done.

6. The game of "spot the real populist" in the corpus was difficult due to uncertainty around actor intentionality but also because the term "populist" has for decades now been used as a pejorative jab in arena politics (it is arguable that similar tactics were used in ancient Rome [e.g. populares] and Athens [e.g. demagogos]). Need to score points on your opponent? Call them a populist! There is also a problem of identifying the populist politician as some agents 
do not behave like traditional political elites and therefore have "populist appeal" but do not (yet) attack hegemons in the name of the (vague) people and so cannot conventionally be understood as populists.

7. As Stavrakakis (2018) suggests through his reading of Lacan, the xenophobic and the authoritarian poles may not simply be mutually attracted but actually feed each other. Yannis Stavrakakis observes how authoritarian populists attempt to unite "the necessary with the impossible in a retroactive loop" where "the real is always foundational in an always escaping and mystifying way”. Reality's marriage with the impossible will always lead to failure he states and, when it does, the Other is there to be blamed so that such populists and their supporters can try again, fail again, and blame again in their illogical but emotionally resonant attempts to get back to the future.

8. Compared to the right's striking influence in the shaping of recent populist politics, the left seems to still be struggling to articulate its voice. Metadata from Google Books, Google Scholar, and Microsoft Academic shows that "right populism" is presently written about between three and five times more than "left populism". Google's Ngram shows that for books written in English the rise of "left populism" happened from the late 1980s to the mid1990s. But thereafter, "left populism" loses prominence and "right populism" reaches its highest recorded frequency in the English language. The Ngram shows that "authoritarian populism", which shares close ties with "right populism", is far more prominent in frequency than "left populism" especially from the late 1970s onward.

\section{REFERENCES}

Agnew, John and Michael Shin. 2017. "Spatializing Populism: Taking Politics to the People in Italy”. Annals of the American Association of Geographers, 107 (4): 915-933.

Albertazzi, Daniele, and Duncan McDonnell. eds. 2008. Twenty-First Century Populism: The Spectre of Western European Democracy. London: Palgrave Macmillan.

Albertazzi, Daniele, and Duncan McDonnell. 2015. Populists in Power. Abingdon, UK: Routledge.

Ali, Omar H. 2010. In the Lion's Mouth: Black Populism in the New South, 1886-1900. Jackson: University Press of Mississippi.

Arguelles, Cleve. 2017. “Grounding Populism: Perspectives from the Populist Publics.” MA Thesis, Department of Political Science, Central European University. https://bit.ly/2LO6Rwl.

Aslanidis, Paris. 2016. "Is Populism an Ideology? A Refutation and a New Perspective”. Political Studies, 64 (1): 88-104.

Aytaç, Erdem and Ziya Öni. 2014. "Varieties of Populism in a Changing Global Context: The Divergent Paths of Erdoðan and Kirchnerismo.” Comparative Politics 47 (1): 41-59.

Babones, Salvatore. 2018. The New Authoritarianism: Trump, Populism and the Tyranny of Experts. London: Polity.

Bailey, David J., Mònica Clua-Losada, Nikolai Huke, Olatz Ribera-Almandoz, and Kelly Rogers. 2018. “Challenging the Age of Austerity: Disruptive Agency after 
the Global Economic Crisis.” Comparative European Politics 16 (1): 9-31. http:/ dx.doi.org/10.1057/s41295-016-0072-8.

Bale, Tim. 2013. “Countering Populism: Snog, Marry, Avoid?” Policy Network, 24 April. https://bit.ly/2LtvcYe.

Bale, Tim, Stijn van Kessel, and Paul Taggart. 2011. "Thrown Around with Abandon? Popular Understandings of Populism as Conveyed by the Print Media: A UK Case Study.” Acta Politica 46 (2): 111-131.

Baum, Bruce. 2017. "Music to Their Ears: Nancy Love's Trendy Fascism, White Nationalism, and the Future of Whiteness." New Political Science 39 (2): 269-276. https://doi.org/10.1080/07393148.2017.1301322.

Berezin, Mabel. 2017. "On the Construction Sites of History: Where Did Donald Trump Come From?” American Journal of Cultural Sociology 17 (5): 322-337. https://www.palgrave.com/it/journal/41290/volumes-issues/special-issues.

Beyme, Klaus von. 2011. "Representative Democracy and the Populist Temptation." In The Future of Representative Democracy, eds. Sonia Alonso, John Keane and Wolfgang Merkel, 50-73. Cambridge: Cambridge University Press.

Boduszyńsky, Mieczystaw P., and Duncan Pickard. 2013. "Libya Starts from Scratch”. Journal of Democracy, 24 (4): 86-96.

Bomberg, Elizabeth, and David Schlosberg. 2008. "US Environmentalism in Comparative Perspective.” Environmental Politics 17 (2): 337-348.

Bouillaud, Christophe. 2016. "Le Mouvement Cinq Etoiles (M5S) de Beppe Grillo en Perspective Historique (1944-2016).” Available online: https://bit.ly/2zWP8fJ.

Bozkurt, Umut. 2013. "Neoliberalism with a Human Face: Making Sense of the Justice and Development Party's Neoliberal Populism in Turkey.” Science \& Society, 77 (3): 372-396.

Brasset, James. 2010. Cosmopolitanism and Global Financial Reform: A Pragmatic Approach to the Tobin Tax. London: Routledge.

Buštíkovà, Lenka and Petra Guasti. 2018. "The State as a Firm: Understanding the Autocratic Roots of Technocratic Populism”. East European Politics and Societies: and Cultures, online first. https://doi.org/10.1177/0888325418791723.

Canovan, Margaret. 1999. “Trust the People! Populism and the Two Faces of Democracy.” Political Studies 47 (1): 2-16. https://doi.org/10.1111\%2F1467-9248.00184.

Canovan, Margaret. 1982. “Two Strategies for the Study of Populism.” Political Studies 30 (4): 544-552. https://doi.org/10.1111/j.1467-9248.1982.tb00559.x.

Corduwener, Pepijn. 2014. "The Populist Conception of Democracy beyond Popular Sovereignty.” Journal of Contemporary European Research 10 (4): 423-437. https://jcer.net/index.php/jcer/article/view/636.

Crotty, William, ed. 2014. Polarized Politics: The Impact of Divisiveness in the US Political System. Boulder, CO: Lynne Rienner.

Curato, Nicole. 2017. "Flirting with Authoritarian Fantasies? Rodrigo Duterte and the New Terms of Philippine Populism." Journal of Contemporary Asia 47 (1): 142-153.

Curato, Nicole. 2016. "Politics of Anxiety, Politics of Hope: Penal Populism and Duterte's Rise to Power.” Journal of Current Southeast Asian Affairs 35 (3): 91-109.

de la Torre, Carlos (ed). 2019. Routledge Handbook of Global Populism. Abingdon: Routledge. 
Diamond, Larry, Marc F. Plattner, and Christopher Walker, eds. 2016. Authoritarianism Goes Global: The Challenge to Democracy. Baltimore: Johns Hopkins University Press.

Dryzek, John. 2008. “Two Paths to Global Democracy.” Ethical Perspectives 15 (4): 469-486. DOI: 10.2143/EP.15.4.2034392.

Dzur, Albert W., and Carolyn M. Hendriks. 2018. “Thick Populism: Democracy-enhancing Popular Participation.” Policy Studies 334-351. https://doi.org/10.1080/ 01442872.2018.1478408.

Dzur, Albert W. 2010. “The Myth of Penal Populism: Democracy, Citizen Participation, and American Hyperincarceration.” The Journal of Speculative Philosophy 24 (4): 354-379. 10.1353/jsp.2010.0016.

Elchardus, Mark, and Bram Spruyt. 2016. "Populism, Persistent Republicanism and Declinism: An Empirical Analysis of Populism as a Thin Ideology." Government and Opposition 51 (1): 111-133. https://doi.org/10.1017/gov.2014.27

Epstein, William M. 2017. The Masses are the Ruling Classes: Policy Romanticism, Democratic Populism, and American Social Welfare. Oxford: Oxford University Press.

Filc, Dani. 2009. The Political Right in Israel: Different Faces of Jewish Populism. London: Routledge.

Filc, Dani. 2011. "Post-Populism: Explaining Neoliberal Populism Through the Habitus.” Journal of Political Ideologies 16 (2): 221-238. https://doi.org/10.1080/13569 317.2011.575685.

Fishman, Robert M. 2016. "Rethinking Dimensions of Democracy for Empirical Analysis: Authenticity, Quality, Depth, and Consolidation.” Annual Review of Political Science 19: 289-309. https://doi.org/10.1146/annurev-polisci-042114-015910.

Frank, Thomas. 2001. One Market Under God. New York: Anchor Books.

Fraser, Nancy. 2017. “Against Progressive Neoliberalism, A New Progressive Populism.” Dissent, January 28. https://bit.ly/2OiGbm2.

Frazer, Phillip. 2017. "When Everybody Does Better: Building a Movement for Change." Griffith Review 57: 70-79.

Fuentes, Juan Francisco. 2013. "Totalitarian Language: Creating Symbols to Destroy Words." Contributions to the History of Concepts 8 (2): 45-66.

Gidron, Noam, and Bart Bonikowski. 2013. "Varieties of Populism: Literature Review and Research Agenda." Weatherhead Centre for International Affairs, Harvard University, Working Paper Series. https://bit.ly/2ghmb6G.

Gomez, Raul, Laura Morales, and Luis Ramiro. 2016. "Varieties of Radicalism: Examining the Diversity of Radical Left Parties and Voters in Western Europe." West European Politics 39 (2): 351-379. https://doi.org/10.1080/01402382.2015.106 4245.

Grabbe, Heather and Nadja Groot. 2014. "Populism in the European Parliament: What Implications for the Open Society?” The International Spectator, 49 (4): 33-46.

Grattan, Laura. 2016. Populism's Power. New York: Oxford University Press.

Halikiopoulou, Daphne, Kyriaki Nanou, and Sofia Vasilopoulou. 2012. "The Paradox of Nationalism: The Common Denominator of Radical Right and Radical Left Euroscepticism.” European Journal of Political Research 51 (4): 504-539. https://doi.org/10.1111/j.1475-6765.2011.02050.x. 
Harrison, Trevor W. 2015. "Petroleum, Politics, and the Limits of Left Progressivism in Alberta." In Alberta Oil and the Decline of Democracy in Canada, eds. Meenal Shrivastava and Lorna Stefanick, 69-88. Edmonton: Athabasca University Press.

Hermet, Guy. 2017. “Histoires des Populismes”. Studia Politica, 17 (4): 481-490. Available online: https://bit.ly/2ONQ51Q.

Ivaldi, Gilles and Maria Elisabetta Lanzone. 2017. "De l’Usage Politique du Peuple Padano: La Construction d'Identité par la Ligue du Nord”. Cahiers d'Études Romanes, 35: 505-520.

Jansen, Robert S. 2015. "Populist Mobilization: A New Theoretical Approach to Populism.” In The Promise and Perils of Populism: Global Perspectives, ed. Carlos de la Torre, Lexington, Kentucky: The University Press of Kentucky. Pp. 159-188. Jennings, Will, and Gerry Stoker. 2016. “The Bifurcation of Politics: Two Englands.” The Political Quarterly 87 (3): 372-382. https://doi.org/10.1111/1467-923X.12228.

Jungar, Ann-Cathrine, and Emil Edenborg. 2018. "Homonationalism in the Nordic Region: PRR Parties and LGBTQ Rights.” Conference paper delivered at IPSA, Brisbane, Monday 23 July. https://bit.ly/2mMuQOh.

Krastev, Ivan. 2012. "The Political Logic of Disintegration: Seven Lessons from the Soviet Collapse.” Centre for European Policy Studies Essay, September. https://bit. ly/2K7lRkd.

Latour, Bruno. 2017. Facing Gaia: Eight Lectures on the New Climatic Regime. Cambridge: Polity.

Lazaridis, Gabriella, Giovanna Campani, and Annie Benveniste. eds. 2016. The Rise of the Far Right in Europe: Populist 'Shifts' and Othering. London: Palgrave.

Liang, Christina Schori, ed. 2016. Europe for the Europeans: The Foreign and Security Policy of the Populist Radical Right. London: Routledge.

Lynch, Catherine. 2018. Liang Shuming and the Populist Alternative in China. Boston: Brill.

Mainwaring, Scott, and Aníbal Pérez-Liñán. 2013. "Lessons from Latin America: Democratic Breakdown and Survival." Journal of Democracy $34 \quad$ (2): 123-137. https://www.journalofdemocracy.org/article/ lessons-latin-america-democratic-breakdown-and-survival.

Malleson, Tom. 2014. After Occupy: Economic Democracy for the $21^{\text {st }}$ Century. Oxford: Oxford University Press.

March, Luke, and Charlotte Rommerskirchen. 2015. “Out of Left Field? Explaining the Variable Electoral Success of European Radical Left Parties.” Party Politics 21 (1): 40-53. https://doi.org/10.1177\%2F1354068812462929.

March, Luke. 2012. "Problems and Perspectives of Contemporary European Radical Left Parties: Chasing a Lost World or Still a World to Win?” International Critical Thought 2 (3): 314-339. https://doi.org/10.1080/21598282.2012.706777.

March, Luke. 2011. Radical Left Parties in Europe. London: Routledge.

Markou, Grigoris. 2017. "The Rise of Inclusionary Populism in Europe: The Case of SYRIZA.” Contemporary Southeastern Europe 4 (1): 54-71.

McCoy, Alfred. 2017. "Global Populism: A Lineage of Filipino Strongmen from Quezon to Marcos and Duterte." Kasarinlan: Philippine Journal of Third World Studies 32 (1-2): 7-54. 
McDonagh, John, Tony Varley, and Sally Shortall, eds. 2009. A Living Countryside?: The Politics of Sustainable Development in Rural Ireland. Farnham: Ashgate.

Mietzner, Marcus. 2018. "Fighting Illiberalism with Illiberalism: Islamist Populism and Democratic Deconsolidation in Indonesia.” Pacific Affairs 91 (2): 261-282. DOI: $10.5509 / 2018912261$.

Mitchell, Lincoln A. 2009. Uncertain Democracy: U.S. Foreign Policy and Georgia's Rose Revolution. Philadelphia: University of Pennsylvania Press.

Moffitt, Benjamin. 2016. The Global Rise of Populism: Performance, Political Style, and Representation. Stanford, USA: Stanford University Press.

Moffitt, Benjamin. 2015. "How to Perform Crisis: A Model for Understanding the Key Role of Crisis in Contemporary Populism”. Government and Opposition 50 (2): 189-217.

Moffitt, Benjamin, and Simon Tormey. 2013. "Rethinking Populism: Politics, Mediatisation and Political Style.” Political Studies 62 (2): 381-397. https://doi. org/10.1111\%2F1467-9248.12032.

Mouffe, Chantal. 2018. For a Left Populism. London: Verso.

Mouffe, Chantal. 2016. "In Defence of Left-Wing Populism.” The Conversation, 30 April. https://bit.ly/1TGUaie.

Morlino, Leonardo, and Francesco Raniolo. 2017. The Impact of the Economic Crisis on South European Democracies. London: Palgrave Macmillan.

Morlino, Leonardo, Daniela Pianna, and Francesco Raniolo. eds. 2013. La Qualità Della Democrazia in Italia. Bologna: Il Mulino.

Mudde, Cas and Rovira Kaltwasser. 2018. "Studying Populism in Comparative Perspective: Reflections on the Contemporary and Future Research Agenda”. Comparative Political Studies: 1-27.

Mudde, Cas, and Cristóbal Rovira Kaltwasser. 2013. "Populism." In The Oxford Handbook of Political Ideologies, eds. Michael Freeden and Marc Steers, Oxford: Oxford University Press. Pp. 1-23.

Mudde, Cas. 2012. "Flemish Nationalism: A New Landscape.” openDemocracy, 15 October. https://bit.ly/2LMH9Iz.

Mudde, Cas, and Cristóbal Rovira Kaltwasser. eds. 2012. Populism in Europe and the Americas: Threat or Corrective for Democracy? Cambridge: Cambridge University Press.

Mudde, Cas. 2004. “The Populist Zeitgeist.” Government \& Opposition 39 (4): 541-563. https://doi.org/10.1111/j.1477-7053.2004.00135.x.

Müller, Jan-Werner. 2016. What Is Populism? Philadelphia: University of Pennsylvania Press.

Müller, Jan-Werner. 2015. "Parsing Populism: Who is and Who is Not a Populist These Days?” Juncture 22 (2): 80-89. https://doi.org/10.1111/j.2050-5876.2015.00842.x.

Munck, Gerardo L. 2009. "Democracy and Development in a Globalized World: Thinking About Latin America from Within.” Studies in Comparative International Development 44 (4): 337-358.

Norris, Pippa, and Ronald Ingleheart. 2018. Cultural Backlash: Trump, Brexit and the Rise of Authoritarian Populism. New York: Cambridge University Press.

Norris, Pippa. 2016. “It's Not Just Trump. Authoritarian Populism is Rising Across the West. Here's Why.” The Washington Post, 11 March. https://wapo.st/2JSGSio. 
Nussbaum, Martha. 2018. The Monarchy of Fear: A Philosopher Looks at Our Political Crisis. New York: Simon \& Schuster.

Oliver, Eric and Wendy Rahn. 2016. “Trump's Voters Aren't Authoritarians, New Research Says. So What Are They?” Washington Post, March 9. https://wapo. st/2xmk07m.

Oppenheim, Lois. 2018. "Making Us Great Again? A Psychoanalytic Discussion of Populism.” Contemporary Psychoanalysis 54 (2): 247-249. https://doi.org/10.1080/ 00107530.2018.1458277.

Pappas, Takis S. 2016. "Modern Populism: Research Advances, Conceptual and Methodological Pitfalls, and the Minimal Definition.” Oxford Research Encyclopedia of Politics. https://bit.ly/21k32Ak.

Pasquino, Gianfranco. 2008. "Populism and Democracy.” In Twenty-First Century Populism: The Spectre of Western European Democracy, eds. Daniele Albertazzi and Duncan McDonnell, 15-29. London: Palgrave Macmillan.

Phongpaichit, Pasuk and Chris Baker. 2008. “Thaksin's Populism.” Journal of Contemporary Asia 38 (1): 62-83.

Puar, Jasbir K. 2017. Terrorist Assemblages: Homonationalism in Queer Times. Durham: Duke University Press.

Qizilbash, Mozaffar. 2008. “Two Views of Corruption and Democracy.” Review of Political Economy 20 (2): 275-291. https://doi.org/10.1080/09538250701819727.

Quaglia, Lucia. 2012. “The 'Old' and the 'New' Politics of Financial Services Regulation in the European Union.” New Political Economy 17 (4): 515-535. https://doi. org/10.1080/13563467.2012.622360.

Roberts, Kenneth. 2015. "Populism, Political Mobilizations, and Crises of Political Representation”. In The Promise and Perils of Populism, edited by Carlos de la Torre. Lexington: The University Press of Kentucky, 140-158.

Rodrik, Dani. 2018. "Populism and the Economics of Globalization.” Journal of International Business Policy 1: 12-33. https://doi.org/10.1057/s42214-018-0001-4.

Rummens, Stefan, and Koen Abts. 2010. "Defending Democracy: The Concentric Containment of Political Extremism.” Political Studies 58 (4): 649-665. https:/| doi.org/10.1111/j.1467-9248.2009.00809.x.

Smith, David Norman, and Eric Hanley. 2018. "The Anger Games: Who Voted for Donald Trump in the 2016 Election, and Why?" Critical Sociology 44 (2): 195212. https://doi.org/10.1177\%2F0896920517740615.

Snyder, Timothy. 2017. On Tyranny: Twenty Lessons from the Twentieth Century. New York: Tim Duggan.

Spruyt, Bram, Gil Keppens, and Filip Van Droogenbroeck. 2016. “Who Supports Populism and What Attracts People to It?” Political Research Quarterly 69 (2): 335-346. https://doi.org/10.1177\%2F1065912916639138.

Stavrakakis, Yannis. 2018. "Jacques Lacan: Negotiating the Psychosocial In and Beyond Language”. In The Routledge Handbook of Language and Politics, eds. Ruth Wodak and Bernhard Forchtner, London: Routledge. Pp. 82-95.

Stavrakakis, Yannis, Ioannis Andreadis, and Giorgos Katsambekis. 2016. "A New Populism Index at Work: Identifying Populist Candidates and Parties in the Contemporary Greek Context.” European Politics and Society 18 (4): 446-464. https://doi.org/10.1080/23745118.2016.1261434. 
Stavrakakis, Yannis. 2014. "The Return of "The People": Populism and Anti-Populism in the Shadow of the European Crisis." Constellations 21 (4): 505-517. https://doi.org/10.1111/1467-8675.12127.

Stavrakakis, Yannis, and Panos Angelopoulos. 2013. "Peuple, Populisme et Anti-Populisme: Le Discours Politique Grec à l'Ombre de la Crise Européenne.” Actuel Marx 54: 107-123. 10.3917/amx.054.0107.

Stockemer, Daniel (ed). 2019. Populism Around the World: A Comparative Perspective. Cham: Springer Nature.

Stoica, Mihnea S. 2017. "Political Myths of the Populist Discourse." Journal for the Study of Religions \& Ideologies 16 (46): 63-76.

Sunstein, Cass, ed. 2018. Can It Happen Here? Authoritarianism in America. New York: Dey Street Books.

Tamás, Gaspar Miklos. 2017. “The Mystery of ‘Populism’ Finally Unveiled.” openDemocracy, 24 February. https://bit.ly/2m4r4RO.

Tormey, Simon. 2018. “Populism: Democracy's Pharmakon?” Policy Studies 39 (3): 260-273. https://doi.org/10.1080/01442872.2018.1475638.

Urbanati, Nadia. 2014. Democracy Disfigured. New York: Columbia University Press.

Weyland, Kurt. 2013. "Latin America's Authoritarian Drift: The Threat from the Populist Left.” Journal of Democracy 24 (3): 18-32.

Weyland, Kurt. 2003. "Neopopulism and Neoliberalism in Latin America: How Much Affinity?” Third World Quarterly 24 (6): 1095-1115.

Weyland, Kurt. 2001. "Clarifying a Contested Concept: Populism in the Study of Latin American Politics.” Comparative Politics 34 (1): 1-22. DOI: 10.2307/422412.

Woods, Dwayne. 2017. "Populism in Search of Its Model." Chinese Political Science Review 2 (3): 253-265.

Woods, Dwayne, and Barbara Wejnert. eds. 2014. Many Faces of Populism: Current Perspectives. Bingley, UK: Emerald Publishing. 